\title{
On Social Knowledge and Its Empirical Investigation in Contemporary Organisations
}

\begin{abstract}
The focus of knowledge management theories on codification and quantification and aspirations to manage knowledge in a similar manner to managing physical resources did not create a stable ground for knowledge management practices in organisations as was expected. Consequently, the theories of social knowledge work take the place of the theories of knowledge management and instead of simplifying they promise to address the issues of complexity. This paper presents a conceptual model of social knowledge - its observable characteristics and associated organisational processes - and aims to help in adopting and contextualising the new theories of knowledge work in organisational research and practice.
\end{abstract}

Keywords: knowledge management, knowledge work, social knowledge.

Tradiciniai žinių vadybos mokslo tyrimai siekia apibrèžti organizacinių žinių struktūrą ir išsiaiškinti, kaip žinios gali būti efektyviau koduojamos, apskaitomos ir kontroliuojamos. Tačiau mokslininkai pripažista, kad vis dar nepavyksta sukurti žinių vadybos mokslo siekiamybės - universaliai pritaikomų žinių vadybos principų. Tuo tarpu vis labiau ịsigali naujos žinių teorijos, besiremiančios socialine žinių samprata, kurios nesiekia žinių vadybos praktikų standartizavimo, bet atvirkščiai - pritaikymo prie savitų organizacijų kontekstų ir kompleksiškumo. Siekiant paskatinti naujųjų teorijų pritaikymą empiriniuose tyrimuose ir praktinèje organizacijų veikloje, šiame straipsnyje pateikiamas teorinis organizacinio žinojimo modelis, besiremiantis socialine žinių samprata, išskiriantis esmines socialinio žinojimo charakteristikas ir su jų raiška susijusius organizacinius procesus.

Raktiniai žodžiai: žinių vadyba, žinių raiška, socialinè žinių samprata.

\section{Introduction}

The understanding of knowledge is continually reshaped throughout the centuries. Western societies are driven by knowledge in one way or another (Knorr Cetina, 1997) - both communities of practitioners and scientists dedicate a great deal of attention to the complexities of creating, growing, sharing and retaining knowledge in organisations; yet, they struggle with the practical implementation of sophisticated theoretical developments (Boland et al., 2001). Furthermore, scientists and practitioners strive to find universal ground in knowledge management, which so far only manages to address a minor part of the issues that the practitioners come up against when dealing with the complexity of knowledge in the unique contexts of their organisations.

I propose that the recent metamorphosis of conceptual developments in knowledge management provides the basis for 
addressing the challenge outlined. It brings the social nature of knowledge in line with its cognitive manifestations and promotes knowledge work as distinct from the management of physical organisational resources; thus, it opens up new pathways for advanced research agendas in this field which were not available by conceptualising knowledge in economic terms. Now, the quest of how to manage knowledge is not for the pursuit of simplification, but the opposite - for the diversity and richness of the practice of knowing and uncovering its meaning in organisational particularities. Nevertheless, social theories of knowledge are adopted in a vague manner and require contextualisation (Michailova, Sidorova, 2010); therefore, based on the most recent developments in knowledge theories, which derive knowledge in social rather than economic organisation in contemporary companies, I develop a model which contains the tool for empirical inquiry of localised knowledge practices and derive the contextualised definitions and meanings of knowledge-sharing processes. With this analysis, I call on scientists and practitioners to critically assess predefined and universal truths used in knowledge management and reflect on the practices and meanings that these practices bring to each specific organisation; and by doing this, bring new theoretical understanding of complex phenomenon without reducing it to structural components.

The object of research is the theories of knowledge in organisational and management research.

The goal of research is to create a conceptual model of the characteristics of social knowledge and the associated organisational processes that would serve as a tool to operationalise the concept of social knowledge in empirical research as well as in managerial practice.

Research methods: the argumentative review of knowledge theories in organisational research and the building of a conceptual model.

Furthermore, the paper is structured as follows. It starts with the discussion of the definition of knowledge by the representatives of two schools in knowledge management research, each having different epistemological assumptions and addressing organisational knowledge issues from different angles: one, from an economic and structural perspective, the other - based on social and processual worldviews. I find that the former, a structural view of knowledge, is what is explicitly or implicitly exploited in most knowledge management research; and that the latter, a social and processual understanding of knowledge, is gaining in momentum but is still less common, yet it has the potential to deal with the issues that arise from a structural approach to knowledge. The paper concludes with the discussion of a conceptual model of the characteristics of social knowledge and the organisational processes that are associated with creating, growing, sharing and retaining social knowledge.

\section{The conceptual definition of knowledge in organisations}

Knowledge is a complex and diversely understood concept, which is closely related to data and information both in theory and practice. As claimed by M. Boisot (1998), it is common to treat knowledge assets as if they were physical assets' (p. XIV) and interchangeably use the concepts of data, information and knowledge as if they 
would be replacing each other (Van den Hoven, 2001). For example, information and knowledge may refer to a common ground, where information only differs in that it is the action of informing, and knowledge - the result of having been informed (Machlup, 1962). Similarly, it is often the case when speaking about codification of technological knowledge as, for example, in the study of M. Balconi (2002) treating information as a structured message, while treating knowledge as a cognitive context of an individual agent (Cowan, David, Foray, 2000). Such lack of distinction is then transferred to social organisational contexts, where knowledge has misleadingly become the focus of management instead of people and organisations (Kreiner, 1999). Only relatively recently, process scholars have drawn attention to intangibility and tacitness as properties of all human knowledge (Tsoukas, 2005b) and promoted the definition of knowledge as a context-dependent and ongoing social activity enacted in a collective practice (Haglund, Halldén, Scheja, 2008; Orlikowski, 2002). Instead of knowledge being understood and managed as a physical asset, knowledge is being redefined as a socio-organisational activity embedded in physical (material) worlds and human practices (Newell et al., 2009). Focusing on the practice of knowing as a particular way of 'understanding the world' (Reckwitz, 2002, p. 253) promises to grasp the fuzzy and intangible nature of human knowledge work instead of purely addressing tangible manifestations, such as data and information management.

It is therefore important to draw distinctions among the three interrelated concepts - knowledge, data and information, and such distinctions are typically made by ordering the three concepts in a sequential and hierarchical way. The mainstream approach places data first, then information and finally knowledge: here 'data' means unprocessed facts, figures items or events (Bell, 1999; Zins, 2007); and 'information' means interpretations or analysis, providing the meaning and contextualising these factual data (Tsoukas, 2005a); lastly, knowledge is at the top of this hierarchy and includes values, beliefs, judgment of events (Tsoukas, 2005a) and action (Gruber, 1988). Neither data nor information are knowledge but both are closely related to knowledge and are a necessary condition for creating it (Davenport, Prusak, 1998). The reverse view considers data as more than knowledge and puts it at the top of the hierarchical order: in contrast to the previous explanation of the hierarchy, knowledge is seen as a prerequisite to information, and consequently information is needed to create data (Tuomi, 1999). Two opposing views stem from different perspectives: first, an intrinsic order of mental data processing, which results in a superior phenomenon - knowledge; second, an extrinsic process of the purposeful and knowledgeable guidance of creating information and data from individual knowledge, which highlights the primacy of knowledge and not the knowledge merely being the mechanical outcome of data processing (see Figure 1 below).

Although superficially the theories may seem to be contradictory as they line up the three concepts in an opposing order, nevertheless they both agree on the fact that knowledge is the most complex organisational phenomena among the three, and, therefore, deserves the most attention.

As one can see, the delineation between knowledge, information and data is ambiguous and defined in a contradictory 


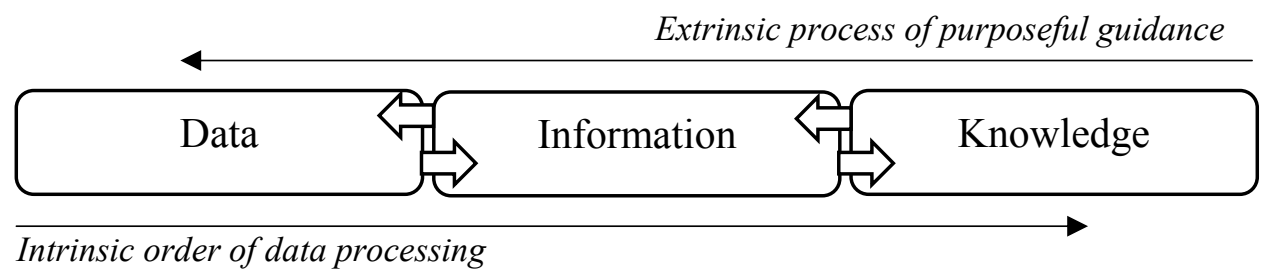

Fig. 1. Hierarchy of data, information and knowledge

manner, and may focus on different aspects of its use in organisations. Following this fuzziness in the definition of knowledge, there are also multiple interpretations of where knowledge resides - is this an individual or collective phenomenon? In management research, the dominant perspective is a structural view of knowledge, which theorises knowledge as belonging to an individual person, and classifies even its collective properties as a distinct type of individual knowledge. There is also an alternative view of knowledge as embedded in social processes where knowledge is treated not as a possession of an individual or a sum of collective thought, but as a product of human activity and social interaction. Research projects based on these ontologically distinct positions bring value to organisational science and management practice in different ways. The first, research based on a structural view of knowledge, aims to simplify the complexity of knowledge (Nicolini, 2016) and understand its structural parts - what kind of knowledge, where and how it serves certain purposes. The second, research based on an understanding of knowledge as a social process, fosters the complexity and embeddedness of knowledge in local contexts and looks into the enactment and material embeddedness of knowing (Newell et al., 2009). Table 1 below summarises the structural and social conceptualisations of knowledge.

These two perspectives on knowledge deserve a more in-depth consideration, which is provided further.

\section{The structural view of knowledge in organisations}

The structural view of knowledge represents epistemology of possession (Cook, Brown, 1999), in which knowledge is treated similarly to other organisational resources and the aim is to simplify management of organisational complexity by standardising the treatment of different

Table 1. Structural and social views of knowledge

\begin{tabular}{|c|c|}
\hline Structural View of Knowledge & Social View of Knowledge \\
\hline Knowledge resides in the individual & $\begin{array}{c}\text { Knowledge manifests through the social activities of } \\
\text { individuals }\end{array}$ \\
\hline Concerned with structure or entity & Concerned with process or action \\
\hline Simplifies contexts for analytic purposes & Fosters embeddedness in complex environments \\
\hline
\end{tabular}


kinds of resources. Therefore, like physical assets, knowledge may be created, acquired, and possessed by an individual or transferred to another individual. Hence such terms as knowledge 'acquisition' and 'transfer' are typical signals of having adopted a structural knowledge perspective in a given research study. Knowledge is treated as residing in an individual person; and collective knowledge activities and terms such as 'organisational knowledge', are used and understood as metaphors (Bhatt, 2002) referring to the sum of knowledge of multiple organisational actors. The structural view of knowledge is driven by the assumption that dividing the concept of knowledge into several types and formulating rules to deal with each type of knowledge helps in managing knowledge in organisations more efficiently (Bhatt, 2002). It contributes to the understanding of knowledge and its role in organisations through generating typologies of knowledge and modelling the relationships between these types (Blackler, 1995). There have been numerous attempts to classify knowledge, and in this paper, I do not pretend to cover all of these classification efforts, but instead, I demonstrate some prevalent principles of the construction of such theories of knowledge in management research. Hence, most typologies are based on two principles: first, on the easiness or difficulty of accessing knowledge (explicit and tacit types of knowledge); second, on the locus where knowledge resides (individual and organisational types of knowledge). The principles of knowledge structure, exemplar theories, applied typologies and principal ideas are summarised in Table 2 below and discussed further.

The assumption under structural approaches to knowledge is that individual cognition is the basis of all knowledge (Newell et al., 2009) in organisations. The differentiation between different kinds of knowledge is constructed based on the fact that some knowledge is quickly and easily expressed and shared with other individuals, but other types of knowledge are less easy to codify and more difficult to

Table 2. The principles and examples of knowledge typologies

\begin{tabular}{|c|c|c|c|}
\hline Knowledge structure & Theory & Typology & Principal idea \\
\hline \multirow{2}{*}{$\begin{array}{c}\text { Based on ease of } \\
\text { accessing knowledge }\end{array}$} & $\begin{array}{c}\text { Nonaka and Takeuchi } \\
(1995) \text {, knowledge } \\
\text { creation }\end{array}$ & $\begin{array}{c}\text { 1. Tacit knowledge } \\
\text { 2. Explicit knowledge }\end{array}$ & $\begin{array}{c}\text { Knowledge is shared and } \\
\text { new knowledge is created } \\
\text { through converting tacit } \\
\text { knowledge to explicit }\end{array}$ \\
\cline { 2 - 4 } & $\begin{array}{c}\text { Collins (2010), tacit } \\
\text { knowledge }\end{array}$ & $\begin{array}{c}\text { Relational } \\
\text { Somatic } \\
\text { Collective }\end{array}$ & $\begin{array}{c}\text { There are three types of } \\
\text { tacit knowledge that range } \\
\text { from easily convertible } \\
\text { to not convertible into } \\
\text { explicit form at all }\end{array}$ \\
\hline Based on both ease \\
of access and locus of \\
knowledge
\end{tabular}


articulate. Such a distinction leads to the construction of two basic types of knowledge both in general and as applied to organisational contexts - explicit and tacit knowledge, also known as codified and non-codified knowledge. Explicit (or codified) knowledge represents what can be expressed in words and numbers, 'transmittable in formal, systematic language' (Nonaka, 1994, p. 16); and tacit (noncodified) knowledge is difficult to express in conventional means of verbalising and 'has a personal quality, which makes it hard to formalise and communicate' (Nonaka, 1994, p. 16). The process of knowledge sharing in organisations is seen as a conversion from tacit to explicit knowledge, which then makes it easily transferable to another person (Teece, 2000). Therefore, tacit-to-tacit knowledge transfer occurs through making it explicit: codifying tacit knowledge of the person transferring it and combining it with the knowledge of a recipient (Roberts, 2000), thereby forming a new kind of tacit knowledge (Nonaka, Takeuchi, 1995). The possibility to explicate and create new knowledge as defined by I. Nonaka and H. Takeuchi (1995) is one of the interpretations of tacit 'knowing' (Gourlay, 2006), first introduced in the philosophical works of Michael Polanyi (1966) and defined as the personal awareness of something that is 'more than we can tell' (Polanyi, 1966, p. 4), which we can only demonstrate by relying on the awareness of others to catch its meaning (ibid). While Nonaka's model largely draws on the existence and importance of tacit knowledge, it mainly stimulated research to look for the ways to explicate such knowledge and make it 'manageable', for example, through information technology infrastructure (Cormican, O'Sullivan,
2003) or developing specific measures of tacit knowledge and incorporating these measures in performance reviews (Foos, Schum, Rothenberg, 2006).

In contrast to the above described model of I. Nonaka and H. Takeuchi (1995), where tacit knowledge may be converted to explicit knowledge, $\mathrm{H}$. M. Collins (2010) treats tacit knowledge as threefold and differently convertible depending on its type. One type of tacit knowledge called relational - might be easily converted to explicit form and thus transferred to another person. It is the simplest type of tacit knowledge to transfer, in fact, Collins even questioned whether it could be called 'tacit' at all because such knowledge is merely temporarily unavailable in our focal minds and may be called on as soon as the person realises it is needed to explicate to some other person. The second type of tacit knowledge - somatic - is also shared with other people in a tacit form and it is entirely possible to convert it into explicit form or create an analogy, however, it is not easily convertible and takes a lot of time and resources, which often cannot be afforded. Then, lastly, the third type of knowledge is called collective: this type of tacit knowledge is irreducible and only transferred through social interactions and practices. While H. M. Collins (2010) attempts to address the issues surrounding knowledge through dividing knowledge into distinct types, he also contributes to the development of knowledge theories by acknowledging that most knowledge is closely tied to the social and practical activities of individuals and to the ways they organise it in particular contexts.

The typologies that make a distinction between individual and organisational knowledge are mostly driven by 
the duality between the individual and their environment. They make an important leap towards acknowledging knowledge as existing beyond an individual (Newell et al., 2009). Based on such approaches, knowledge is classified into types by pointing to its 'location': inside or outside of an individual. Individual knowledge is what resides inside people's heads (Gherardi, 2000) and is perceived by those individuals alone (Bhatt, 2002, p. 32). Organisations are also viewed as cognitive enterprises and systems of shared beliefs agreed upon by consensus are called organisational knowledge (Lyles, 1997). As the definition in this stream of research is based on a cognitive understanding of knowledge, it is still not clear how organisational (systemic) knowledge is defined in more specific terms. More often, though, the definition of organisational knowledge is not provided at all but used as a parallel concept to individual knowledge on an organisational level (e.g., Bharati, Zhang, Chaudhury, 2015; Loebbecke, van Fenema, Powell, 2016).

J. C. Spender (1996) attempts to transcend the classical structural definition of knowledge and builds a classification based on two dimensions: difficulty of accessing knowledge - explicit (also called 'objective') and implicit (discussed together with 'tacit' knowledge), and locus individual and social (also called 'organisational') (Spender, 1996). Using a two by two matrix, J. C. Spender bridges the two methods of knowledge classification, and from this follow four types of knowledge: conscious knowledge (explicit individual knowledge, e.g. codified in personal notes or uncodified in an individual's memory), automatic (implicit individual knowledge, e.g., recognition), objectified (explicit social, which is sharable among people, knowledge, e.g., data, procedures, systems) and collective knowledge (implicit social knowledge, e.g., teamwork, culture). The two types that are a product of explicit and implicit knowledge types at a social level essentially clarify the distinction between the more formal and less formal natures of knowledge in organisations: explicit social knowledge, which Spender calls 'objectified' (also, Spender refers to it as 'organisational knowledge'), is the type of information that is 'evaluated according to institutionalised standards'; whereas 'collective' knowledge is 'the outcome of the interplay between the conscious and automatic types of knowledge' (meaning, between the explicit and implicit knowing of a person), and 'between the individual and collective types of knowledge as they interact through the social processes' (Spender, 1996, p. 71). Similarly to J. C. Spender, F. Blackler (1993) uses activity theory (Vygotsky, 1962) and bases the structure of knowledge on either individual or collective levels ('collective interpretation') of knowledge (Blackler, 1995); however, he departs from the typical individual and collective knowledge structures and attempts to develop the notion of knowledge as materially embedded and process-based 'knowing' (learning). While the overall schemes of these knowledge structures are still largely based on individual cognition, one of the contributions of J. C. Spender's and F. Blackler's theorisations is that their theories acknowledge the social or, in other terms, collective dimension of knowledge, bringing structures of meaning and materiality into play and thus building a bridge to a new understanding of knowledge as a social phenomenon. 


\section{The processual and practice views of knowledge in organisations}

By the end of the twentieth century, management scientists were increasingly acknowledging that knowledge is not manageable in the same way as physical resources (Boisot, 2002). Two new streams of knowledge theories in organisational research, more commonly referred to as theories of 'knowing' or 'knowledge work', discard the explanation of knowledge as individual cognitive activity and proclaim knowledge to be fundamentally social: these approaches represent the epistemology of action (Chiva, Alegre, 2005); a so-called 'process' view of knowledge; the epistemology of practice (Cook, Brown, 1999) and a practice view in organisational research. Both process and practice views treat knowledge as a process and not as an entity and are helpful in analysing how knowing is enacted in particular contexts (Newell et al., 2009). They do not pretend to be creating generalisable ways of manipulating knowledge in organisations. The metaphors we use to express our ideas have 'enormous impact on how we reason about knowledge' (Andriessen, 2008, pp. 5-6); therefore, researchers within these streams also use different terminology and embrace the use of 'knowing' instead of 'knowledge', as well as 'enacting knowledge' and 'knowledge work' as opposed to 'knowledge transfer' or 'knowledge management', which are common terms used to refer to knowledge from the structural points of view. Process and practice scholars approach knowledge as an undivided unity and inherently social, which first of all means asserting that knowledge is an integral phenomenon and is not separable into distinct types; and second, it means speaking of knowledge as a process - what people do in organisations - as opposed to knowledge as a static and compartmentalised concept (Blackler, 1995) which is owned by people or organisations. Process and practice approaches encompass complementary arguments of the equivocality, dynamics and context dependence of knowledge (Newell et al., 2009). The key characteristics of process and practice views are summarised in Table 3 below, and further the arguments for each of these two perspectives are discussed.

Process scholars claim that structural theories of knowledge wrongly adopted the concept of tacit knowledge by Michael Polanyi (1966) (Tsoukas, 2005b) and instead of taking the tacitness of knowledge as a property of all human knowledge, assigned

Table 3. Theories of social knowledge

\begin{tabular}{|c|c|c|}
\hline $\begin{array}{c}\text { Theoretical approach on } \\
\text { knowledge }\end{array}$ & Focus on & Principal idea \\
\hline Process view & $\begin{array}{c}\text { Human action and the social } \\
\text { nature of human knowledge }\end{array}$ & $\begin{array}{c}\text { Knowledge is a dynamic, negotiated } \\
\text { and relational process of sensemak- } \\
\text { ing, which encompasses both cogni- } \\
\text { tive and social dimensions }\end{array}$ \\
\hline Practice view & $\begin{array}{c}\text { Human action, the social nature of } \\
\text { knowledge and its embeddedness } \\
\text { in material arrangements }\end{array}$ & $\begin{array}{c}\text { Knowledge resides and can be seen } \\
\text { in what people do, say, believe and } \\
\text { reflect through material artefacts }\end{array}$ \\
\hline
\end{tabular}


it only to certain kinds of knowledge. Explicit knowledge does not exist as a separate type, as there is always an element of tacit knowing underlying it. Even if we find a way of decoding tacit knowledge and stating it in an externalised manner this decodifying process itself is more than we can describe in words and remains incommunicable. Process theorists do not reduce knowledge sharing to its 'transfer' through articulation (Tsoukas, 2005b) and suggest that knowledge is not observable independently of its context and does not exist 'out-there'; therefore, attempts to derive independent and separable parts of knowledge only bring partial and fragmented understanding of this concept. Additionally, treating knowledge as purely personal and residing inside of an individual is problematic too: assumptions behind the definition of 'individual' or 'personal' may even misleadingly attribute interdependent activities performed by multiple actors to the cognitive activities of a single person - to a personal 'belief' (Gourlay, 2006). Instead of treating knowledge as a 'thing' (possession of a person), process scholars define it as a dynamic, negotiated and relational process of 'sensemaking', which helps to discriminate 'within and across contexts' (Newell et al., 2009, p. 14). The process view of knowledge implies attending to social nature and embeddedness of knowledge, which encompass both 'the individual cognitive aspects of knowledge as well as its social nature' (Newell et al., 2009, p. 6).

The practice perspective has a lot in common with the process perspective, however, in addition, it focuses on how knowing is a part of human action, or in other words, human practice (Newell et al., 2009), and how it is embedded in materiality. Practice scholars view knowledge as enabled in practices and specific material and social contexts (Newell et al., 2009). Knowing is an action, which is 'informed by meaning drawn from a particular group context' (Cook, Brown, 1999, p. 60) and 'negotiated through social interaction' (Newell et al., 2009, p. 16). Sociality, as in the process view, is not the total of individuals' knowledge but the interrelatedness of the social lives of those individuals, which emerge through their actions (Feldman, Orlikowski, 2011). Practice theorists ascribe an important role to materiality and material objects and 'knowledge is conceived largely as a form of mastery that is expressed in the capacity to carry out a social and material activity' which also includes feelings, expectations and meanings (Nicolini, 2012, p. 5). Following this, organisational knowledge is a shared understanding and a set of norms that people develop while working in a group. Knowledge resides and can be seen in what people do, say, believe and reflect through material artefacts, which they use and produce (Newell et al., 2009).

\section{Conceptual model of social knowledge}

As discussed in earlier sections, the theories of knowledge management and knowledge work represent two distinct views of knowledge in organisations. First is a structural view of knowledge which is an approach to knowledge that aims to simplify and manage the complexity of organisational knowledge through reducing it to a few types of knowledge that can be created, stored, managed or transferred like any physical organisational resource. 
It promotes the individualist and dual natures of knowledge, and contributes to the scholarly conversation on the dichotomy and opposition of mind and body, as well the dichotomy of thought and action (Gherardi, 2000). The structural approach to knowledge is widely adopted in management research and tends to analyse knowledge as an isolated entity and prescribe a simplified 'objective' definition of knowledge when dealing with complex practical environments. On the other hand, the social view of knowledge as a socially embedded process refuses this partitioning of knowledge and treats it as one integral process. There are two broad streams of research that promote the social understanding of knowledge - the process and practice views - and which are very similar in how they define the concept. Knowledge as process is neither 'out-there' nor individual property but is the process of knowing shared among organisation members. In addition to process, practice scholars stress the material embeddedness of knowledge in local contexts - knowledge as a socially and materially interwoven activity, which constitutes organisational practices, and which itself is constituted by these practices. Therefore, structural and social views hold fundamentally different assumptions about what constitutes knowledge, what constitutes social life and about the separability of knowledge from its contexts. The use of these assumptions in structural and social views of knowledge consequently give rise to different strengths and weaknesses, which have implications on the applicability of these theoretical approaches in empirical research and the potential to produce findings which could meaning- fully explain knowledge practices in organisational contexts, as summarised in Table 4 below.

Based on the analysis and the comparison of two theoretical approaches of knowledge, the social view encapsulates a potential solution for the issues that impede current research progress in knowledge management in organisations. It connects the social, cognitive and material dimensions, which constitute practices of knowing, treats knowing as an activity and is focused on 'how knowledge happens' instead of 'what knowledge is'. Additionally, it approaches knowing as produced and reproduced in a local context and by local actors; therefore, the local knowing and its meaning is superior to general conceptualisations and universal prescriptions of knowledge management practices in organisations. As is apparent, even the proponents of structural knowledge theories, which concentrate primarily on the cognitive nature of knowledge, widely acknowledge that knowledge is not only individual but also of a social nature, which nevertheless they treat as a secondary issue and still define it differently from what is understood to constitute the social world in terms of process scholars. Moreover, empirical research studies tend to focus on the aspects that are easier to measure, so explicit and close-ended manifestations of knowledge work. Despite that such treatment of knowledge does not produce the desired universal guidance to success, surprisingly, yet it persists as a sounder, more scientific and more reliable form of analysis than individualised and non-generalisable solutions to organisational challenges. The less 
Table 4. The strengths and weaknesses of the structural and social views of knowledge

\begin{tabular}{|c|c|c|c|}
\hline & \multirow{2}{*}{$\begin{array}{l}\text { Structural View of } \\
\text { Knowledge }\end{array}$} & \multicolumn{2}{|c|}{ Social View of Knowledge } \\
\hline & & Knowledge as process & Knowledge as practice \\
\hline \multirow[t]{3}{*}{ Key assumptions } & $\begin{array}{l}\text { Knowledge is a cognitive } \\
\text { activity, and is separate } \\
\text { from bodily activities }\end{array}$ & $\begin{array}{l}\text { Knowing is an integral } \\
\text { cognitive and social } \\
\text { process }\end{array}$ & $\begin{array}{l}\text { Knowing is an integral } \\
\text { cognitive, bodily and } \\
\text { social activity }\end{array}$ \\
\hline & $\begin{array}{l}\text { Social is understood as a } \\
\text { collective sum of multiple } \\
\text { individual realities }\end{array}$ & $\begin{array}{l}\text { Social is understood as a } \\
\text { dynamic, negotiated and } \\
\text { relational process }\end{array}$ & $\begin{array}{c}\text { Social is understood as } \\
\text { an inter-individual reality } \\
\text { embedded in interrelated } \\
\text { people's lives }\end{array}$ \\
\hline & $\begin{array}{l}\text { Knowledge may be } \\
\text { isolated from other } \\
\text { human activities and } \\
\text { analysed this way }\end{array}$ & \multicolumn{2}{|c|}{$\begin{array}{l}\text { Knowing is embedded and cannot be separated from } \\
\text { its contexts and therefore needs to be analysed within } \\
\text { those contexts }\end{array}$} \\
\hline Strengths & $\begin{array}{l}\text { Proposes the frameworks } \\
\text { that make knowledge } \\
\text { relatively easily empirically } \\
\text { explored in organisations }\end{array}$ & \multicolumn{2}{|c|}{$\begin{array}{l}\text { Reflects the complexity of knowledge work and con- } \\
\text { textual embeddedness in organisations }\end{array}$} \\
\hline Weaknesses & $\begin{array}{l}\text { Knowledge is reduced to } \\
\text { a 'manageable' resource } \\
\text { and, therefore, it fails to } \\
\text { account for more complex } \\
\text { knowledge manifestations }\end{array}$ & \multicolumn{2}{|c|}{$\begin{array}{l}\text { Proposes sophisticated frameworks which are difficult } \\
\text { to apply in empirical research }\end{array}$} \\
\hline
\end{tabular}

straightforward choice of empirically exploring knowledge work in organisations as a social process demands greater explanation of how we can empirically observe the interrelated lives of individuals, as the social knowledge is defined to be. With regard to this, several characteristics of knowledge work need to be taken into account: multiplicity and power structure of knowledge claims, contextuality and embeddedness in language, human action and materiality.

Organisation members may hold different views and knowledge of some subjects, which they negotiate to arrive at some collective action, and there is no 'true' knowledge as such; therefore, it is difficult to arrive at any conclusive and generalisable statements of organisational knowledge management. It is well known that knowledge claims are easier to accept as 'truthful' or 'valid' if coming from a more powerful and authoritative person (Newell et al., 2009). Therefore, it is more beneficial for organisations to analyse how 'true' knowledge is being constructed in social interactions and negotiations within this organisation than to try to arrive at some objective truth. Organisations, like the people who lead them and work within them, are different in how creative or calculative they are (Spender, 1996), which means different firms also require different ways of creating, gathering, sharing and retaining knowledge. Knowledge also consists of individual and collective meanings, which organisational members express, continue, change and persist through their words and actions. 
Knowledge is embedded in human language and actions no less than it resides in their heads. While most would agree that knowledge is more tacit than explicit in its nature, it also matters how we treat the relationship of individual agency to knowledge: if we agree that knowledge is not purely individual, but also a social phenomenon, then it must have implications on how organisations approach the issue of knowledge retention (Boisot, 2002). In order to successfully retain and develop organisational knowledge, the company needs routines that allow its employees to spend enough time near their more experienced colleagues, seeing how they work, and to have social time at work which is impossible to directly account for, but which builds shared understanding of the work that the team performs. Additionally, routines and successful knowledge work rely on continuous engagement in the consistent development of their material basis, including IT and other systems, which allow personal knowledge and meanings to tacitly attach to these materials and artefacts.

When empirically exploring knowledge work in organisations, the focal processes of observation and interpretation encompass creating, growing, sharing and retaining knowledge through language or artefacts (materials or working tools). In organisational practice, knowledge, data and information are interchangeable and may not have clear boundaries between them. Similarly to what was previously discussed as being present in some theoretical discourses (Van den Hoven, 2001), knowledge, information and data are simultaneously produced and reproduced, and regard- less of whether they are shared through language, written or encoded form, they hold the elements of meanings that are conventionally attached depending on a local organisational or broader business collective understanding. Therefore, knowledge is inherently cultural and may not be fully appreciated by an outsider who is not familiar with the local practices and embedded meanings - so called 'best practices' may be different and unique to the firm (Nag, Gioia, 2012). However, it does not imply that individual meanings do not exist - these may be captured by observing individual and work environment characteristics, enacted practices, stated purposes and expressed meanings, or continual negotiations and renegotiations of power plays. The efficiency of organisational knowledge work may be appreciated by observing and recording how organisations manage to continuously engage and develop their material and social environments and collectively retain the experiences of their individual members (see Figure 3 below).

\section{Conclusions}

This paper analyses the theories of knowledge management and knowledge work from both the structural and the social (social includes processual and practice) perspectives. The understanding of knowledge as a fundamentally social phenomenon uncovers new possibilities for in-depth scientific exploration of organisational knowledge; furthermore, it uncovers more opportunities for organisational practitioners to arrange meaningful and relevant knowledge work tailored to 


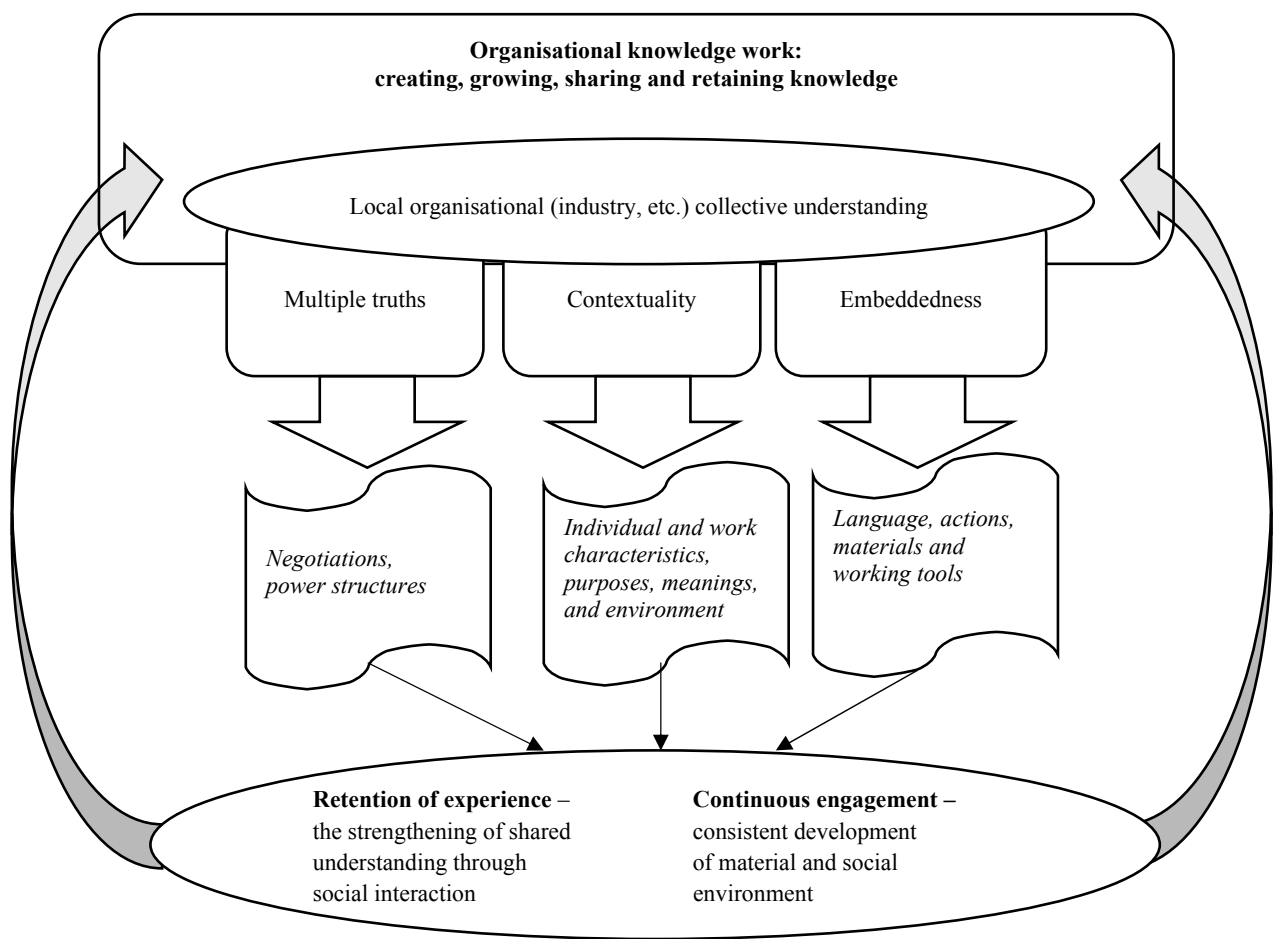

Fig. 3. Characteristics of social knowledge and the associated organisational processes

the unique settings of their organisations. Based on the extant literature review, it is apparent that the social nature of knowledge is increasingly prioritised over the analysis of its cognitive characteristics. Therefore, the new theories of social knowledge serve as a basis for the model of characteristics of social knowledge and the associated organisational processes. The model integrates characteristics of social knowledge (multiple truths, contextuality and embeddedness), empirical manifestations (negotiations and power structures; individual and work characteristics; individual purposes and meanings; work environments; language; actions; materials and working tools) and two major mechanisms (retention of experience and continuous engagement) which promote creating, growing, sharing and retaining knowledge in organisations. This paper contributes to the theory of knowledge in organisational and management research by suggesting the ways to structure investigations of knowledge work in empirical research studies. 


\section{References}

1. Andriessen, D. G. (2008). Stuff or Love? How Metaphors Direct Our Efforts to Manage Knowledge in Organisations // Knowledge Management Research \& Practice. Vol. 6, No. 1, pp. 5-12. doi:10.1057/palgrave.kmrp.8500169.

2. Balconi, M. (2002). Tacitness, Codification of Technological Knowledge and the Organisation of Industry // Research policy. Vol. 31, No. 3, pp. 357-379.

3. Bell, D. (1999). The Coming of Post-Industrial Society: A Venture in Social Forecasting. Special Anniversary Edition / with a New Foreword by the Author. - New York: Basic Books.

4. Bharati, P., Zhang, W., Chaudhury, A. (2015). Better Knowledge with Social Media? Exploring the Roles of Social Capital and Organizational Knowledge Management // Journal of Knowledge Management. Vol. 19, No. 3, pp. $456-475$.

5. Bhatt, G. D. (2002). Management Strategies for Individual Knowledge and Organizational Knowledge // Journal of Knowledge Management. Vol. 6, No. 1, pp. 31-39. doi: $10.1108 / 13673270210417673$.

6. Blackler, F. (1993). Knowledge and the Theory of Organizations: Organizations as Activity Systems and the Reframing of Management // Journal of management studies. Vol. 30, No. 6, pp. 863-884.

7. Blackler, F. (1995). Knowledge, Knowledge Work and Organizations: An Overview and Interpretation // Organization Studies. Vol. 16, No. 6, pp. 1021-1046.

8. Boisot, M. (2002). The Creation and Sharing of Knowledge / In The Strategic Management of Intellectual Capital and Organizational Knowledge, pp. 65-77.

9. Boisot, M. H. (1998). Knowledge Assets: Securing Competitive Advantage in the Information Economy. - Oxford: OUP.

10. Boland, R. J., Singh, J., Salipante, P., Aram, J. D., Fay, S. Y., Kanawattanachai, P. (2001). Knowledge Representations and Knowledge Transfer // Academy of Management Journal. Vol. 44, No. 2, pp. 393-417. doi:10.5465/3069463.

11. Chiva, R., Alegre, J. (2005). Organizational Learning and Organizational Knowledge: Towards the Integration of Two Approaches // Management learning. Vol. 36, No. 1, pp. 49-68.
12. Collins, H. M. (2010). Tacit and Explicit Knowledge. - Chicago; London: The University of Chicago Press.

13. Cook, S. D., Brown, J. S. (1999). Bridging Epistemologies: The Generative Dance between Organizational Knowledge and Organizational Knowing // Organization Science. Vol. 10, No. 4, pp. 381-400.

14. Cormican, K., O'Sullivan, D. (2003). A Collaborative Knowledge Management Tool for Product Innovation Management // International Journal of Technology Management. Vol. 26, No. 1, pp. 53-67.

15. Cowan, R., David, P. A., Foray, D. (2000). The Explicit Economics of Knowledge Codification and Tacitness // Industrial \& Corporate Change. Vol. 9, No. 2.

16. Davenport, T. H., Prusak, L. (1998). Working Knowledge: How Organizations Manage What They Know. - Harvard Business School Press.

17. Feldman, M. S., Orlikowski, W. J. (2011). Theorizing Practice and Practicing Theory // Organization Science. Vol. 22, No. 5, p. 12401253. doi:10.1287/orsc.1100.0612.

18. Foos, T., Schum, G., Rothenberg, S. (2006). Tacit Knowledge Transfer and the Knowledge Disconnect // Journal of Knowledge Management. Vol. 10, No. 1, pp. 6-18. doi:10.1108/13673270610650067.

19. Gherardi, S. (2000). Practice-Based Theorizing on Learning and Knowing in Organizations // Organization. Vol. 7, No. 2, pp. 211-223. doi:10.1177/135050840072001.

20. Gourlay, S. (2006). Conceptualizing Knowledge Creation: A Critique of Nonaka's Theory // Journal of Management Studies. Vol. 43, No. 7, pp. 1415-1436. doi:10.1111/j.1467-6486.2006.00637.x.

21. Gruber, T. R. (1988). The Acquisition of Strategic Knowledge. - University of Massachusetts.

22. Haglund, L., Halldén, O., Scheja, M. (2008). The Contextuality of Knowledge: An Intentional Approach to Meaning-Making and Conceptual Change / In International Handbook of Research on Conceptual Change, ed. S. Vosniadou. - New York: Routledge, Taylor \& Francis group.

23. Knorr Cetina, K. (1997). Sociality with Objects: Social Relations in Postsocial Knowledge Societies // Theory, Culture \& Society. Vol. 14, No. 4, pp. 1-30. 
24. Kreiner, K. (1999). Knowledge and Mind: The Management of Intellectual Resources / In Advances in Managerial Cognition and Organizational Information Processing, ed. J. F. Porac, Garud, Raghu. - Greenwich, CT: JAI Press Ltd.

25. Loebbecke, C., van Fenema, P. C., Powell, P. (2016). Managing Inter-Organizational Knowledge Sharing // The Journal of Strategic Information Systems. Vol. 25, No. 1, pp. 4-14. doi:10.1016/j.jsis.2015.12.002.

26. Lyles, M. A., Schwenk, C. R. (1997). Top Management, Strategy and Organizational Knowledge Structures / In Knowledge in Organisations, ed. L. Prusak. - Boston: Butterworth-Heinnemann.

27. Machlup, F. (1962). The Production and Distribution of Knowledge in the United States. - Princeton, New Jersey: Princeton University Press.

28. Michailova, S., Sidorova, E. (2010). Knowledge Management in Transition Economies: Selected Key Issues and Possible Research Avenues // Organizations and Markets in Emerging Economies. Vol. 1, No. 1, pp. 68-81.

29. Nag, R., Gioia, D. A. (2012). From Common to Uncommon Knowledge: Foundations of Firm-Specific Use of Knowledge as a Resource // Academy of Management Journal. Vol. 55, No. 2, pp. 421-457. doi:10.5465/amj.2008.0352.

30. Newell, S., Robertson, M., Scarbrough, H., Swan, J. (2009). Managing Knowledge Work and Innovation. - Basingstoke; New York: Palgrave Macmillan.

31. Nicolini, D. (2012). Practice Theory, Work, and Organization: An Introduction (1st ed.). Oxford: Oxford University Press.

32. Nicolini, D. (2016). Knowing in Organizations: A Practice-Based Approach: A Practice-Based Approach. - London, New York: Routledge.

33. Nonaka, I. (1994). A Dynamic Theory of Organizational Knowledge Creation // Organization Science. Vol. 5, No. 1, pp. 14-37. doi:10.1287/orsc.5.1.14.

34. Nonaka, I., Takeuchi, H. (1995). The Knowledge-Creating Company: How Japanese Companies Create the Dynamics of Innovation. - USA: Oxford University Press.

35. Orlikowski, W. J. (2002). Knowing in Practice: Enacting a Collective Capability in Distributed Organizing // Organization Science. Vol. 13, No. 3, pp. 249-273.
36. Polanyi, M. (1966). The Tacit Dimension. Garden City, N.Y.: Doubleday.

37. Reckwitz, A. (2002). Toward a Theory of Social Practices: A Development in Culturalist Theorizing // European Journal of Social Theory. Vol. 5, No. 2, pp. 243-263.

38. Roberts, J. (2000). From Know-How to ShowHow? Questioning the Role of Information and Communication Technologies in Knowledge Transfer // Technology Analysis \& Strategic Management. Vol. 12, No. 4, pp. 429-443. doi:10.1080/713698499.

39. Spender, J.-C. (1996). Organizational Knowledge, Learning and Memory: Three Concepts in Search of a Theory // Journal of Organizational Change Management. Vol. 9, No. 1, p. 63-78.

40. Teece, D. J. (2000). Strategies for Managing Knowledge Assets: The Role of Firm Structure and Industrial Context // Long Range Planning. Vol. 33, No. 1, pp. 35-54.

41. Tsoukas, H. (2005a). Complex Knowledge: Studies in Organizational Epistemology. Oxford: Oxford Univ. Press.

42. Tsoukas, H. (2005b). Do We Really Understand Tacit Knowledge? / In Managing Knowledge: An Essential Reader, ed. R. T. Little Stephen. Vol. 107. - London, Thousand Oaks, New Delhi: Sage Publications India Pvt Ltd.

43. Tuomi, I. (1999). Data Is More Than Knowledge: Implications of the Reversed Knowledge Hierarchy for Knowledge Management and Organizational Memory. http://ieeexplore.ieee. org/xpls/abs_all.jsp?arnumber $=772795$

44. Van den Hoven, J. (2001). Information Resource Management: Foundation for Knowledge Management // Information Systems Management. Vol. 18, No. 2, pp. 80-83. doi:10 $.1201 / 1078 / 43195.18 .2 .20010301 / 31281.12$.

45. Vygotsky, L. S. (1962). Thought and Language. Mit Press, Cambridge, Mass.

46. Zins, C. (2007). Conceptual Approaches for Defining Data, Information, and Knowledge // Journal of the American Society for Information Science and Technology. Vol. 58, No. 4, pp. 479493. doi:10.1002/asi.20508.

The paper submitted: January 2, 2019

Prepared for publication: June 30, 2019 


\section{Irina LIUBERTE்}

\section{SOCIALINĖ ŽINIỤ SAMPRATA IR IŠTYRIMO GALIMYBĖS ŠIUOLAIKINĖSE ORGANIZACIJOSE}

\section{S a n t r a k a}

Organizacinès žinios - tai sudetinga ir ịvairiai apibrèžiama sąvoka, nuolat traukianti Vakarų šalių mokslininkų ir praktikų demesị (Knorr Cetina, 1997). Nors žinios yra vienas labiausiai vertinamų organizacinių resursų, jos taip pat glaudžiai siejasi su informacija ir duomenimis, todèl neretai kyla painiava apibrèžiant šias sąvokas, brèžiant takoskyrą tarp jų ir analizuojant jų ryšius (Balconi, 2002; Cowan et al., 2000; Gruber, 1988; Machlup, 1962; Tsoukas, 2005a; Tuomi, 1999). Teorijos dvejopai aiškina, kaip žinios, informacija ir duomenys susiję tarpusavyje, tai yra ar duomenys ir informacija reikalingi norint sukurti žinias, ar atvirkščiai iš turimų žinių pirmiausia sukuriama informacija ir duomenys. Tačiau abi teorijos sutaria dèl to, kad žinioms turètų būti skiriama daugiausia dèmesio.

Nepaisant sparčiai populiarejjančios alternatyvios - socialinès - žinių sampratos, kuri remiasi procesine ir kontekstine žinių raiškos analize, struktūrinès žinių vadybos teorijos vis dar dominuoja empiriniuose tyrimuose. Tradiciniai žinių vadybos mokslo tyrimai remiasi žinių valdymo - „turejjimo" - samprata (Cook ir Brown, 1999) ir priskiria žinias individualioms žmogaus savybėms. Šios teorijos siekia išsiaiškinti organizacinių žinių struktūrą ir nustatyti, kaip žinios gali būti efektyviau koduojamos, apskaitomos ir kontroliuojamos, kartu prilyginant jas kitiems organizacijų resursams, taip pat ir fiziniams (Boisot, 1998). Struktūriniam požiūriui žinių vadyboje būdingas tokių terminų kaip „žinių igijimas“ ar „žinių perdavimas“ vartojimas. Žinios dažniausiai klasifikuojamos remiantis tuo, kaip lengvai jos gali būti pasiekiamos aplinkiniams žmonems ir jų paplitimu asmeniniame ar kolektyviniame lygmenyje. Straipsnyje pristatomos trys struktūrinès žinių teorijos, iliustruojančios šiuos žinių klasifikavimo principus. Pirmoji I. Nonakos ir H. Takeuchi (1995) žinių kūrimo teorija išskiria išreikštines (lengvai pasiekiamas kitiems žmonèms) ir neišreikštines (sunkiau pasiekiamas kitiems žmonėms) žinias bei paaiškina, kaip šios struktūros pagrindu organizacijos kuria naujas žinias. Antroji klasifikacija remiasi panašiu žinių pasiekiamumo principu, tačiau išskiria net tris neišreikštinių žinių tipus - sąsajines (reliacines), somatines ir kolektyvines (Collins, 2010): sąsajinès žinios yra lengviausiai eksternalizuojamos ir komunikuojamos kitiems organizacijų nariams; daugiau energijos reikalauja pasidalinimas somatinèmis žiniomis; tuo tarpu kolektyvinès žinios yra sudètingiausiai arba visai nepasiekiamos - „neperduodamos“ - aplinkiniams. Trečia teorija sujungia abu žinių pasiekiamumo ir jų paplitimo principus ir šių dviejų dimensijų pagrindu išskiria keturis žinių tipus (Spender, 1996): sąmoningas (išreikštines individualias), automatines (neišreikštines individualias), objektyvizuotas (išreikštines organizacines) ir kolektyvines (neišreikštines organizacines) žinias.

Tuo tarpu naujesnès - socialinès - teorijos teigia, kad žinių klasifikavimas yra iš esmès klaidinantis, nes žinios yra vientisas socialinis konstruktas, turintis tiek išreikštumo, tiek neišreikštumo požymių (Tsoukas, 2005b). Taip pat teigiama, kad valdomos ne žinios, bet organizacijos ir jų nariai (Kreiner, 1999). Remiantis socialine žinių samprata, žinios yra neatskiriamos nuo konteksto, igyjamos per veiklą, jutimus ir perteikiamos per bendravimą (Chiva ir Alegre, 2005; Cook ir Brown, 1999; Feldman ir Orlikowski, 2011; Newell et al., 2009), todèl jos iš esmès negali būti valdomos tokiais pat būdais, kokiais valdomi fiziniai organizacijų resursai, ar traktuojamos kaip išskirtinai kognityviniai ir individualūs žmonių gebejjimai (Gherardi, 2000). Šiuo metu išskiriamos dvi socialinių žinių teoriju kryptys: viena grindžiama procesiniu požiūriu, o kita - praktikos teorija (Newell et al., 2009). Procesinio požiūrio atstovai apibrèžia žinojimą kaip procesą - organizacijų narių kognityvinès ir socialinès (tarpusavio bendravimo) veiklos sąveiką. Praktikos teorijos atstovai taip pat sieja organizacines žinias su jos narių socialiniu gyvenimu, tačiau papildomai skiria dèmesio žinojimui, igyjamam per jutimus bei santykị su materialiu pasauliu (ịkūnytam žinojimui) (Newell et al., 2009; Nicolini, 2012). Procesinio ar praktikos požiūrių atstovai vengia „daiktiško“ žinių ịvardijimo, todèl linkę „žinių“ ir „žinių perdavimo“ sąvokas pakeisti kitomis, tokiomis kaip „žinojimas ar „žinių raiška“, kurios geriau atspindi visumini žinių supratimą. Kadangi šios teorijos nesiekia redukuoti organizacijų aplinkos kompleksiškumo, jas taip pat sudètingiau taikyti empiriniuose tyrimuose. Taigi, siekiant užpildyti šią spragą organizacijų ir vadybos tyrimuose ir palengvinti socialinès žinių sampratos operacionalizavimą, straipsnyje pateikiamas konceptualus žinių raiškos modelis. Jis remiasi socialinių žinių teorijų analize ir išskiria esmines žinojimo organizacijoje charakteristikas 
(daugialypiškumą, kontekstualumą, socialinį, kognityvinị, materialų ir kultūrinị susietumą), pateikia šių charakteristikų pavyzdžius, kuriuos stebint žinojimas gali būti tiriamas empiriškai. Modelyje taip pat išskiriamos per bendravimą ir materialius jutimus ịveiklinamos (patirties išlaikymo ir nuolatinio įsitraukimo) praktikos, kurios igalina organizacijų tobulejimą ir tolesnị organizacinio žinojimo kūrimą, auginimą, sklaidą ir išlaikymą. 